\title{
Influence of Cropping Systems on Stem Rot (Sclerotium rolfsii), Meloidogyne arenaria, and the Nematode Antagonist Pasteuria penetrans in Peanut
}

\author{
P. Timper, N. A. Minton, and A. W. Johnson, USDA ARS, P.O. Box 748, Tifton, GA 31793; T. B. Brenneman \\ and A. K. Culbreath, Department of Plant Pathology, University of Georgia, P.O. Box 748, Tifton 31793; G. W. \\ Burton, USDA ARS, P.O. Box 748, Tifton, GA 31793; and S. H. Baker and G. J. Gascho, Department of Crop \\ and Soil Sciences, University of Georgia, Coastal Plain Experiment Station, P.O. Box 748, Tifton 31793
}

\begin{abstract}
Timper, P., Minton, N. A., Johnson, A. W., Brenneman, T. B., Culbreath, A. K., Burton, G. W. Baker, S. H., and Gascho, G. J. 2001. Influence of cropping systems on stem rot (Sclerotium rolfsii), Meloidogyne arenaria, and the nematode antagonist Pasteuria penetrans in peanut. Plant Dis. 85:767-772.

The effect of crop rotation (main plots) and pesticide treatment (subplots) on stem rot (Sclerotium rolfsii), Meloidogyne arenaria, and the nematode antagonist Pasteuria penetrans was determined in a field experiment. The field site was naturally infested with all three organisms. Peanut $(\mathrm{P})$ was rotated with 2 years of either cotton $(\mathrm{Ct})$, corn $(\mathrm{C})$, or bahiagrass $(\mathrm{B})$. The pesticide treatments for the peanut crop were aldicarb (31 g a.i. per 100-m row), flutolanil (1.7 kg a.i./ha), aldicarb + flutolanil, and a control without either pesticide. Populations of $M$. arenaria were lower in peanut in the Ct-Ct-P than in P-P-P, C-C-P, or B-B-P plots and tended to be lower in plots treated with aldicarb. Abundance of $P$. penetrans endospores was highest in the P-P-P plots, intermediate in the B-B-P rotations, lowest in all other rotations, and was unaffected by aldicarb. The high endospore densities in the P-P-P plots may have contributed to the uncharacteristically low nematode populations in the monoculture. Incidence of stem rot in peanut was lowest in treatments with flutolanil, intermediate in the control, and highest in treatments with aldicarb alone. The greater canopy cover in aldicarb-treated plots may have created a conducive environment for $S$. rolfsii infection.
\end{abstract}

Additional keywords: Arachis hypogaea, gall indices, Gossypium hirsutum, Paspalum notatum, root-knot nematode, suppressive soil, thrips, Zea mays

Crop yields are generally higher in rotation with other crops than in monoculture. Rotation increases yields through improvements in soil nutrition and structure, and reduction of plant pathogens, primarily those infecting the plant stems and roots (29). Crop rotations for suppression of disease and plant-parasitic nematodes must include one or more years of a poor host plant for pathogen reproduction. Pathogens that rely primarily on a host for proliferation will decline in numbers on a nonhost and cause less damage to the following susceptible crop. The rate of decline and the length of rotation necessary for effective suppression depend on the longevity of the pathogen survival stage.

Yield increases when peanut (Arachis hypogaea) is grown in rotation compared with continuous cultivation are correlated with disease and nematode suppression

Corresponding author: P. Timper

E-mail: ptimper@tifton.cpes.peachnet.edu

Accepted for publication 31 March 2001.

Publication no. D-2001-0509-01R

This article is in the public domain and not copyrightable. It may be freely reprinted with customary crediting of the source. The American Phytopathological Society, 2001.
$(4,13,23,25)$. Two important pathogens of peanut that are managed by rotation are Meloidogyne arenaria, the peanut rootknot nematode, and Sclerotium rolfsii, the causal organism of southern stem rot. In the southeastern United States and Texas, $M$. arenaria reduces peanut yield by 3 to $15 \%$ (15). Stem rot is favored by warm wet conditions within the plant canopy and is the most damaging fungal disease of peanut in the southeastern United States (16). Rotating peanut with 2 years of cotton (Gossypium hirsutum), corn (Zea mays), castor bean (Ricinus communis), or bahiagrass (Paspalum notatum) reduces the incidence of stem rot and populations of $M$. arenaria in the susceptible peanut crop $(13,23,25,26)$.

The suppression of plant pathogen populations by crop rotation may also reduce populations of their host-specific antagonists. One such antagonist is Pasteuria penetrans, an obligate parasite of Meloidogyne species. The endospores of this bacterium attach to the cuticle of migrating juveniles and infect only after the nematode enters the root and begins to feed (28). Vegetative colonies and endospores are formed within the living host nematode. When roots containing infected females decompose, endospores are released into soil. Endospores of $P$. penetrans are resis- tant to environmental extremes and remain infective for several years in the laboratory; however, their long-term viability in field soil is unknown (5). In soils heavily infested with $P$. penetrans, a large proportion of the migratory second-stage juveniles acquire endospores. Mobility of these encumbered juveniles is reduced; thus fewer nematodes enter the root system $(7,18)$, and many of those that enter the root and establish a feeding site do not produce eggs (28). Natural infestations of $P$. penetrans may be sufficiently high to suppress populations of Meloidogyne spp. $(3,20,30)$.

Although it is well established that rotating peanut with cotton, corn, and bahiagrass suppresses soilborne diseases and plant-parasitic nematodes, the effect of these rotations on the abundance of $P$. penetrans is unknown. Moreover, the interaction of these rotations with fungicide (flutolanil) and nematicide (aldicarb) treatments commonly used to control $S$. rolfsii and $M$. arenaria, respectively, was not determined in previous studies. Our objectives were to compare the effect of different crop rotations and pesticides on numbers of $M$. arenaria and $P$. penetrans, incidence of stem rot, and yield of peanut. The effect of the different treatments on thrips damage to peanut was also determined because these insects can reduce canopy width early in the season (10), thus affecting the canopy microclimate and possibly infection by $S$. rolfsii. Previous reports from this study presented data from 1991 to 1996, but did not include data on $P$. penetrans $(13,14)$. We are reporting disease, nematode, thrips, and yield data from 1997 to 1999 from the peanut crop only and $P$. penetrans data from 1998 and 1999 for all crop sequences.

\section{MATERIALS AND METHODS}

The study was initiated in 1991 on the Gibbs Farm at the Coastal Plain Experiment Station, Tifton, GA. The soil was a Tifton loamy sand (fine-loamy, siliceous, thermic Plinthic Kandiudult; pH 6.1) naturally infested with $S$. rolfsii, $M$. arenaria race 1 , and $P$. penetrans. The soil was plowed to a depth of 20 to $25 \mathrm{~cm}$ and shaped into beds $1.8 \mathrm{~m}$ wide and 10 to 15 $\mathrm{cm}$ high. Main plots $(11.0 \times 7.6 \mathrm{~m})$ consisted of four treated beds and two untreated border beds. Data were collected from the treated beds. 
The experiment was a split-plot in a crop rotation treatments in the main plots and pesticide treatments in the subplots. All treatments were replicated four times. The rotations were peanut $(\mathrm{P})$ rotated with 2 years of either corn (C-C-P), cotton (Ct$\mathrm{Ct}-\mathrm{P}$ ), or bahiagrass (B-B-P), and continuous peanut (P-P-P), cotton $(\mathrm{Ct}-\mathrm{Ct}-\mathrm{Ct})$, or corn $(\mathrm{C}-\mathrm{C}-\mathrm{C})$. There were three sequences of each rotation (e.g., C-C-P, C-P-C, and P-C-C), so that a crop of corn, cotton, bahiagrass, and peanut was produced each year. Each of these sequences was replicated four times. Four crop-specific pesticide treatments were applied to peanut, corn, and cotton (Table 1). There were no pesticide treatments for bahiagrass.

Peanut (100 to $112 \mathrm{~kg} / \mathrm{ha}$ ), corn (18 to $19 \mathrm{~kg} / \mathrm{ha}$ ), and cotton (11 to $12 \mathrm{~kg} / \mathrm{ha}$ ) were seeded in two rows $0.9 \mathrm{~m}$ apart on the plant bed. In 1997, the following cultivar substitutions were made: peanut cv. Georgia Green for Florunner, cotton cv. Stoneville LA 887 (moderately resistant to $M$. incognita) for Georgia King, and the corn hybrid Asgrow RX 938 for Asgrow RX 945. Bahiagrass cv. Tifton 9 was seeded at $22.4 \mathrm{~kg} / \mathrm{ha}$ over the entire main plot in March or April. To control broadleaf weeds in the bahiagrass plots, 2,4-D amine was broadcast at $2.2 \mathrm{~kg}$ a.i./ha after planting. Cultural practices, fertilization, and additional pest management for the peanut, corn, cotton, and bahiagrass crops were based on recommendations for the area $(9,22)$. Peanuts were dug and inverted based on an optimum maturity index. When pod moisture was ca. $14 \%$, pods were harvested with a combine, dried to ca. $8 \%$, and weighed.

At planting, midseason, and harvest, 10 soil cores $(2.5 \mathrm{~cm}$ diameter $\times 15 \mathrm{~cm}$ deep) randomized, complete-block design with

were collected from each subplot for extraction of $M$. arenaria second-stage juveniles (J2). The 10 soil cores were combined, and the nematodes were extracted from a $150 \mathrm{~cm}^{3}$ subsample by centrifugal flotation (12). Gall indices and incidence of stem rot were determined for each subplot immediately after peanuts were inverted. Roots, pods, and pegs from 10 plants per subplot were examined for galls of $M$. arenaria and rated on a 1 to 5 scale based on the percentage of the root system with galls: $1=$ no galls, $2=1$ to $25 \%, 3=$ 26 to $50 \%, 4=51$ to $75 \%$, and $5=76$ to $100 \%$. Stem rot incidence was based on the number of disease loci per $15.2 \mathrm{~m}$ of row, where a locus represents one or more plants in $30 \mathrm{~cm}$ of row infected with $S$. rolfsii. Thrips (Frankliniella spp.) damage to peanut was visually estimated on 40 leaflets per subplot in June of each year.

The abundance of $P$. penetrans endospores in soil was estimated with a bioassay using greenhouse-cultured $\mathrm{J} 2$ of Meloidogyne arenaria, race 1 . To obtain $\mathrm{J} 2$ for the bioassay, nematode eggs were extracted from roots of tomato (Lycopersicon esculentum) cv. Rutgers using $\mathrm{NaOCl}$ (11) and placed in hatching dishes. The hatching dishes were composed of two layers of tissue paper supported by a screen and placed in a dish containing enough water to form a thin layer over the tissue. The J2 that hatched on the tissue and migrated into the water were collected daily. Suspensions of $\mathrm{J} 2$ were bubble-aerated at room temperature for no more than 4 days before use. Soil for the bioassay was collected in July of 1998 and 1999 from the a and d subplot treatments of each crop (Table 1). The soil was sampled as described above, and a $100 \mathrm{~cm}^{3}$ subsample was added to a 250-ml flask. Tap water was added to the

Table 1. Pesticide treatments applied to the subplots for each crop ${ }^{\mathrm{a}}$

\begin{tabular}{|c|c|c|}
\hline $\begin{array}{l}\text { Crop } \\
\text { Pesticide }\end{array}$ & Quantity applied & Application method \\
\hline \multicolumn{3}{|l|}{ Peanut } \\
\hline a, Aldicarb 15G & $31.0 \mathrm{~g}$ a.i./100-m row & $\begin{array}{l}\text { 30-cm-wide band ahead of } \\
\text { planter }\end{array}$ \\
\hline b, Flutolanil $50 \mathrm{WP}$ & $\begin{array}{l}7.8 \mathrm{~g} \text { a.i. } / 100-\mathrm{m} \text { row } \\
0.8 \mathrm{~kg} \text { a.i./ha } \\
(1.7 \mathrm{~kg} \text { a.i./ha total })\end{array}$ & $\begin{array}{l}60 \mathrm{DAP}^{\mathrm{b}} \text { in a } 30-\mathrm{cm} \text {-wide } \\
\text { band and } 90 \text { DAP broadcast }\end{array}$ \\
\hline c, Aldicarb + flutolanil & Same as above & Same as above \\
\hline $\mathrm{d}$, Control & $\ldots$ & $\ldots$ \\
\hline \multicolumn{3}{|l|}{ Corn } \\
\hline a, Ethoprop 10G & $22.6 \mathrm{~g}$ a.i./100-m row & $\begin{array}{l}30-\mathrm{cm} \text {-wide band ahead of } \\
\text { planter }\end{array}$ \\
\hline b, Terbufos $15 \mathrm{G}$ & $13.8 \mathrm{~g}$ a.i./100-m row & In furrow \\
\hline c, Ethoprop + terbufos & Same as above & Same as above \\
\hline $\mathrm{d}$, Control & $\cdots$ & $\ldots$ \\
\hline \multicolumn{3}{|l|}{ Cotton } \\
\hline a, Aldicarb 15G & $15.5 \mathrm{~g}$ a.i./100-m row & $\begin{array}{l}\text { 15-cm-wide band ahead of } \\
\text { planter }\end{array}$ \\
\hline b, Mepiquat-chloride & $0.03 \mathrm{~kg}$ a.i./ha & Sprayed at first bloom \\
\hline $\begin{array}{l}\text { c, Aldicarb + mepiquat- } \\
\text { chloride }\end{array}$ & Same as above & Same as above \\
\hline d, Control & $\ldots$ & $\ldots$ \\
\hline
\end{tabular}

\footnotetext{
a No pesticide treatments were applied to the bahiagrass plots.
}

${ }^{\mathrm{b}}$ Days after planting. flask to saturate the soil and bring the final volume to $200 \mathrm{ml}$. The flask was sealed with a rubber stopper and shaken vigorously by hand for $5 \mathrm{~s}$. The soil particles were allowed to settle for $5 \mathrm{~s}$ before 100 $\mathrm{ml}$ of the soil-water suspension was decanted into another $250 \mathrm{~cm}^{3}$ flask. Assay nematodes $(1,500 \mathrm{~J} 2$ of $M$. arenaria) were added to the flasks, and the flasks were placed on a rotary shaker at $160 \mathrm{rpm}$. After $24 \mathrm{~h}$, the assay nematodes were extracted from the soil-water suspension by centrifugal flotation (12), and the mean number of endospores adhering to the first 30 nematodes encountered was determined at $\times 400$ magnification with an inverted microscope.

The data presented, except for the abundance of $P$. penetrans endospores, were collected from the peanut crop. Because the data were not normally distributed, they were converted to ranks using the Wilcoxon rank sum test and then were subjected to analysis of variance (ANOVA). A mixed model was used to test the random effect of year and the fixed effects of rotation and pesticide treatment on peanut yield, gall index, numbers of $M$. arenaria $\mathrm{J} 2$, stem rot loci, and thrips damage. The effect of rotation and year on endospores of $P$. penetrans per assay nematode was determined using a two-way ANOVA. A $t$ test was used to determine the effect of aldicarb on endospore abundance in the continuous peanut plots. Differences among means were determined using Tukey's HSD test $(P \leq 0.05)$. All data were analyzed using the Statistical Analysis System (version 7.0, SAS Institute Inc, Cary, NC).

\section{RESULTS}

Soil densities of $M$. arenaria $\mathrm{J} 2$ at harvest in continuous peanut were similar to densities in peanut following all other crops (Fig. 1A). However, soil densities were lower in peanut following 2 years of cotton than following 2 years of either corn or bahiagrass. Densities of J2 also were lower in plots receiving aldicarb or aldicarb + flutolanil than in control plots but were not lower than in plots receiving flutolanil alone (Fig. 1B). There was no interaction between rotation and pesticide treatment on J2 densities. Root-gall indices on peanut were influenced by both rotation $(P<0.0001)$ and pesticide treatment $(P<$ $0.0001)$; however, the effect of pesticide treatment was not consistent among the different rotations (rotation $\times$ pesticide interaction, $P=0.02$ ). Gall indices in plots receiving aldicarb or aldicarb + flutolanil were generally smaller, but not always significantly smaller, than in the control or flutolanil-alone plots (Fig. 2). The effect of rotation on root galling was more pronounced in plots not treated with aldicarb. For example, in control plots, gall indices were smaller $(P \leq 0.05)$ following 2 years of cotton (1.7) than following 2 years of 
bahiagrass (2.6); gall indices in continuous peanut (2.4) and in peanut following 2 years of corn (1.8) were similar to the cotton and bahiagrass rotations (Fig. 2, statistical differences not shown on figure). In plots treated with flutolanil alone, gall indices were smaller in peanut following 2 years of cotton than in all other crop sequences.

Abundance of $P$. penetrans endospores in the different crop sequences was similar

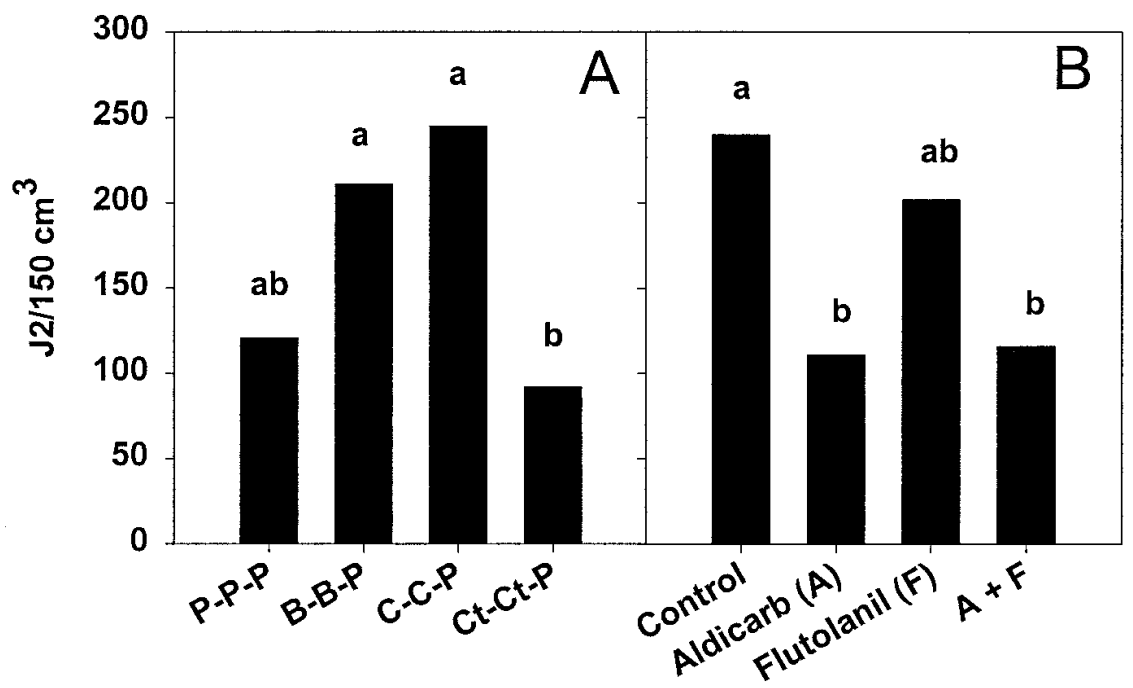

Rotation

\section{Pesticide treatment}

Fig. 1. Densities of second-stage juveniles (J2) of Meloidogyne arenaria in peanut plots at harvest. A, Effect of crop rotation on density of J2. Crops in rotation were peanut (P), bahiagrass (B), corn (C), and cotton (Ct). Bars are the combined means of all pesticide treatments, 3 years, and four replicates $(n=48)$. B, Effect of pesticide treatments on density of J2. Treatments were aldicarb $15 \mathrm{G}$ at 31 g a.i. per $100 \mathrm{~m}$ of row, flutolanil $50 \mathrm{WP}$ at $1.7 \mathrm{~kg}$ a.i./ha, aldicarb + flutolanil, and controls without either aldicarb or flutolanil. Bars are the combined means of all rotations, 3 years, and four replicates $(\mathrm{n}=48)$. Bars within a figure with the same letter are not significantly different $(P>0.05)$.

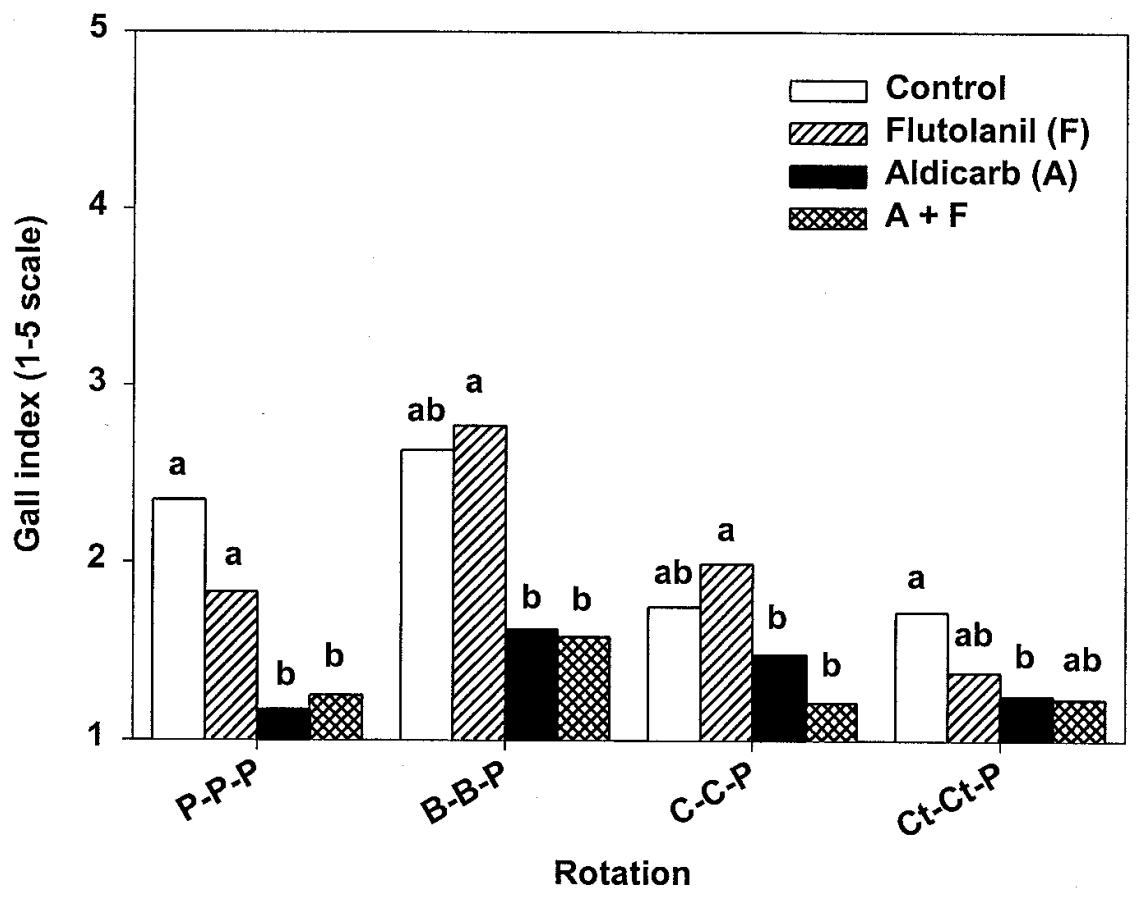

Fig. 2. Effect of crop rotation and pesticide treatment on root-gall indices of Meloidogyne arenaria at harvest on peanut. The 1 to 5 scale is based on the percentage of the root system with galls: $1=$ no galls; $2=1$ to $25 \% ; 3=26$ to $50 \% ; 4=51$ to $75 \%$; and $5=76$ to $100 \%$. Crops in rotation were peanut $(\mathrm{P})$, bahiagrass $(\mathrm{B})$, corn $(\mathrm{C})$, and cotton $(\mathrm{Ct})$. Pesticide treatments were aldicarb $15 \mathrm{G}$ at $31 \mathrm{~g}$ a.i. per $100 \mathrm{~m}$ of row, flutolanil $50 \mathrm{WP}$ at $1.7 \mathrm{~kg}$ a.i./ha, aldicarb + flutolanil, and controls without either aldicarb or flutolanil. There was an interaction between rotation and pesticide treatment $(P=0.02)$. Bars are means of 3 years and four replicates per year. Bars within a group with the same letter are not significantly different $(P>0.05)$.

in 1998 and 1999; therefore, the data for the 2 years were combined (Fig. 3). The number of endospores per assay nematode was highest in the continuous peanut plots, intermediate in the B-B-P rotations, and lowest in all other crop sequences. In continuous peanut plots, the number of endospores per assay nematode was similar in plots receiving aldicarb $(21.2 \pm 2.9 ; \bar{x}$ \pm SE) and control plots $(18.9 \pm 3.9)$.

Incidence of southern stem rot was greater in continuous peanut than in peanut following 2 years of bahiagrass, and similar to all crop sequences in peanut following corn and cotton (Fig. 4A). Incidence of the disease was highest in the aldicarbalone plots, intermediate in the control plots, and lowest in the flutolanil and aldicarb + flutolanil plots (Fig. 4B). There was no interaction between rotation and pesticide treatment in the incidence of stem rot. Data were collected on Tomato spotted wilt virus and Rhizoctonia limb rot severity in peanut, but both diseases were present at very low levels in all 3 years of the study (data not shown).

The percentage of leaflets damaged by thrips was not affected by rotation but was less $(P<0.0001)$ in plots treated with aldicarb alone $(8.3 \pm 0.6)$ or in aldicarb + flutolanil $(8.8 \pm 0.7)$ than in the control (28.3 $\pm 0.4)$ or flutolanil alone $(28.5 \pm 0.4)$ plots.

Peanut yield was $12 \%$ greater following 2 years of corn and $22 \%$ greater following 2 years of bahiagrass than in continuous peanut (Fig. 5A). Peanut yield following 2 years of cotton was similar to continuous peanut. Aldicarb alone did not increase peanut yields compared with control plots. Flutolanil alone and aldicarb + flutolanil increased peanut yields by 16 and $26 \%$

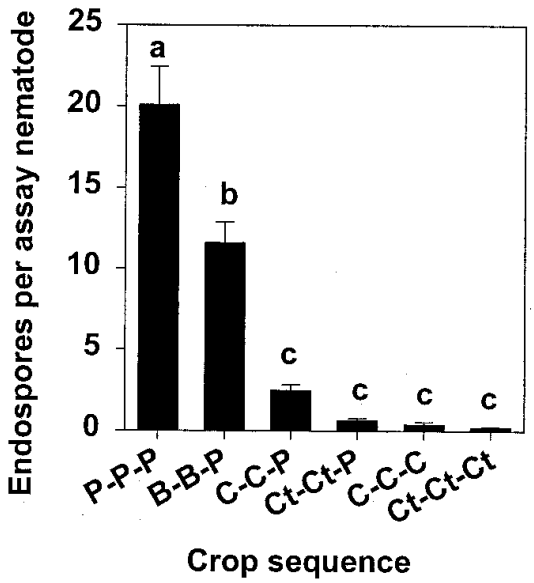

Fig. 3. Effect of crop rotation and monoculture on abundance of Pasteuria penetrans endospores. Assay nematodes were second-stage juveniles of greenhouse-cultured Meloidogyne arenaria. Crops were peanut $(\mathrm{P})$, bahiagrass (B), corn $(\mathrm{C})$, and cotton $(\mathrm{Ct})$. Bars are the mean of 2 years, three sequences, and eight replicates per year for the rotations $(n=48)$, and eight replicates per year for the monocultures $(\mathrm{n}=16)$. Bars with the same letter are not significantly different $(P>0.05)$. 
compared with control plots, respectively (Fig. 5B). There was no interaction between rotation and pesticide treatment on yield of peanut.

\section{DISCUSSION}

Populations of $M$. arenaria were expected to be lower in peanut following 2 years of either cotton, bahiagrass, or corn than in peanut monoculture. However, nematode numbers ( $\mathrm{J} 2$ densities and gall indices) were reduced only in the peanutcotton rotation. Cotton and bahiagrass are nonhosts for $M$. arenaria; therefore, populations of this nematode should decline during cultivation of these crops. Indeed, rotating peanut with these crops has reduced populations of $M$. arenaria compared with peanut monoculture in other studies $(23,26)$. A lack of nematode suppression in the bahiagrass-peanut rotation was previously reported by Johnson et al.

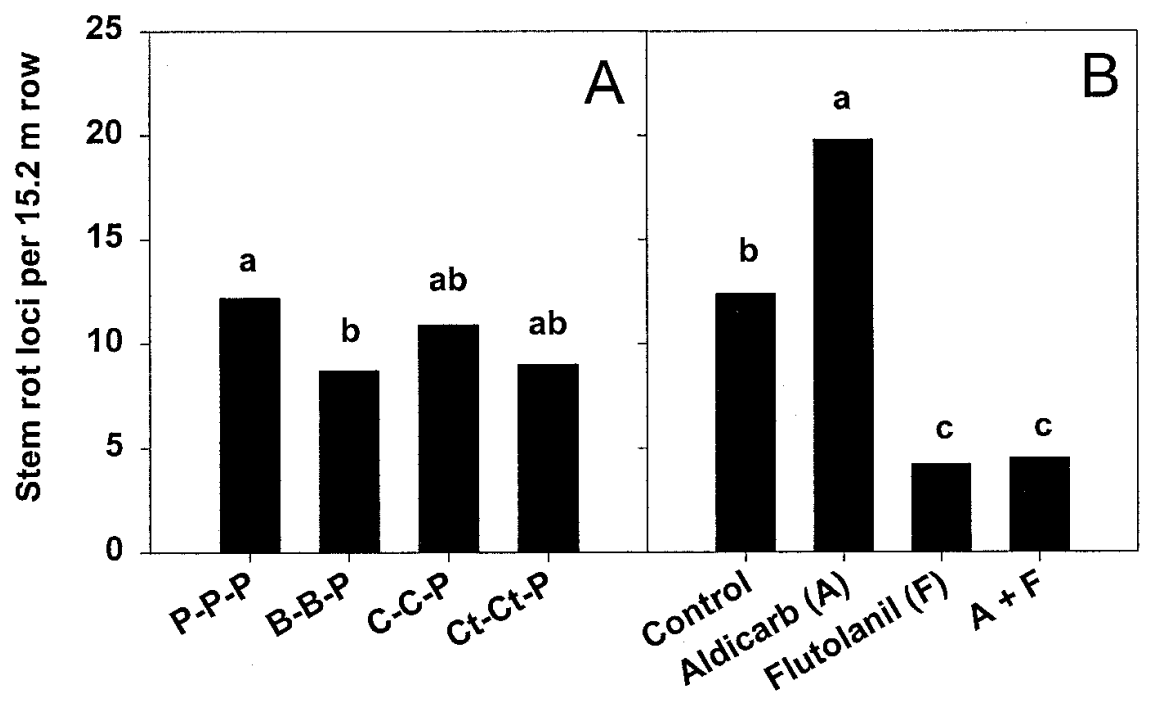

Rotation

Pesticide treatment

Fig. 4. Incidence of southern stem rot in peanut caused by Sclerotium rolfsii. A, Effect of crop rotation on disease incidence. Crops in rotation were peanut $(\mathrm{P})$, bahiagrass $(\mathrm{B})$, corn $(\mathrm{C})$, and cotton $(\mathrm{Ct})$. Bars are the combined means of all pesticide treatments, 3 years, and four replicates $(n=48)$. B, Effect of pesticide treatments on disease incidence. Treatments were aldicarb $15 \mathrm{G}$ at $31 \mathrm{~g}$ a.i. per $100 \mathrm{~m}$ of row, flutolanil $50 \mathrm{WP}$ at $1.7 \mathrm{~kg}$ a.i./ha, aldicarb + flutolanil, and controls without either aldicarb or flutolanil. Bars are the combined means of all rotations, 3 years, and four replicates $(\mathrm{n}=$ 48). Bars within a figure with the same letter are not significantly different $(P>0.05)$.

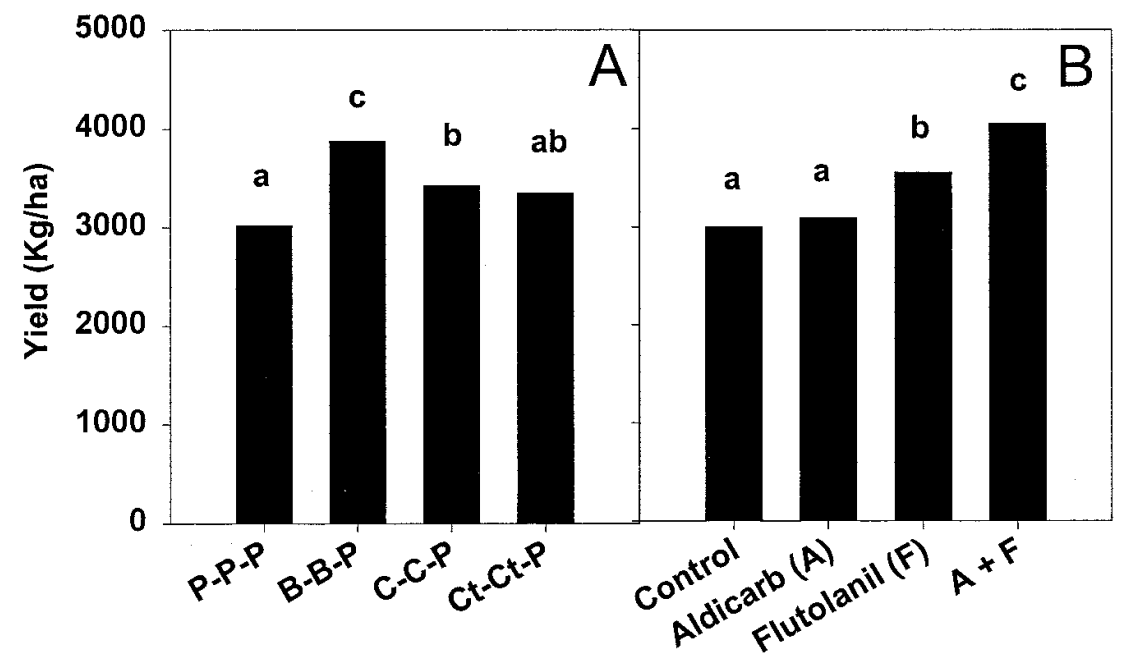

Rotation

Pesticide treatment

Fig. 5. Effect of crop rotation and pesticide treatments on yield of peanut. A, Crops in rotation were peanut $(\mathrm{P})$, bahiagrass $(\mathrm{B})$, corn $(\mathrm{C})$, and cotton $(\mathrm{Ct})$. Bars are the combined means of all pesticide treatments, 3 years, and four replicates $(n=48)$. B, Pesticide treatments were aldicarb $15 \mathrm{G}$ at $31 \mathrm{~g}$ a.i. per $100 \mathrm{~m}$ of row, flutolanil $50 \mathrm{WP}$ at $1.7 \mathrm{~kg}$ a.i./ha, aldicarb + flutolanil, and controls without either aldicarb or flutolanil. Bars are the combined means of all rotations, 3 years, and four replicates $(\mathrm{n}=48)$. Bars within a figure with the same letter are not significantly different $(P>0.05)$.

(13) and may be due to the presence of weeds, which were numerous in the bahiagrass plots the first year after planting, but were virtually eliminated by the second year when the bahiagrass became more densely established. Some of these weeds may have been hosts for $M$. arenaria. Most corn hybrids are poor hosts for $M$. arenaria. Nevertheless, because some reproduction occurs on corn, it may not be as effective as a nonhost in suppressing populations of this nematode. However, a previous report from this study showed that corn was as effective as cotton in reducing populations of $M$. arenaria (13). Reproduction of $M$. arenaria varies considerably among corn hybrids (8). Perhaps the hybrid used from 1991 to 1996 supported less nematode reproduction than the hybrid planted from 1997 to 1999.

Our inability to demonstrate suppression of $M$. arenaria following 2 years of either bahiagrass or corn compared with continuous peanut may be due, in part, to the uncharacteristically low nematode populations in the continuous peanut plots. Despite the continuous planting of hosts for $M$. arenaria, gall indices on peanut have declined at the Gibbs Farm field site from above 3.5 in the 1970 s to 1.5 in 1989 (Fig. 6; N. A. Minton, unpublished). This decline in the nematode population may be due to parasitism by $P$. penetrans. In 1988, endospores of this parasitic bacterium were first observed adhering to $M$. arenaria $\mathrm{J} 2$ collected at the field site. In two greenhouse experiments, soil from this site suppressed reproduction of $M$. arenaria by 100 and $86 \%$ compared with the same soil that had been heat-treated to kill $P$. penetrans endospores and other nematode antagonists (20; N. A. Minton, unpublished). Presumably, continuous cropping of host plants for M. arenaria before 1991 resulted in a nematode-suppressive soil, which was

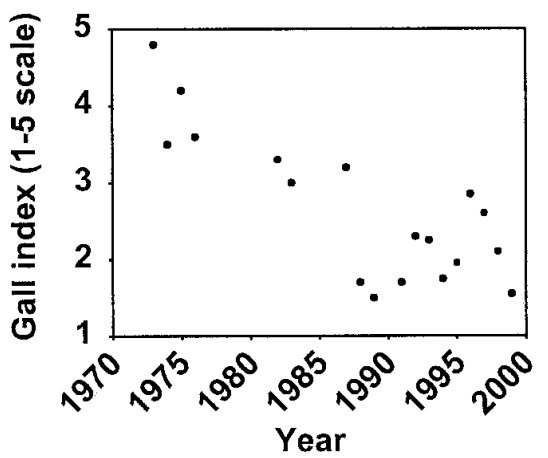

Fig. 6. Root-gall indices of Meloidogyne arenaria on peanut over a 27 -year period at the Gibbs Farm, Tifton, GA. The 1 to 5 scale is based on the percentage of the root system with galls: $1=$ no galls; $2=1$ to $25 \% ; 3=26$ to $50 \% ; 4=51$ to $75 \%$; and $5=76$ to $100 \%$. The current study was initiated at this field site in 1991 and concluded in 1999. In the years without a data point, another host of $M$. arenaria (soybean or okra) was planted instead of peanut. 
maintained in the continuous peanut plots. In these plots, endospore densities were greater than in any other cropping sequence. Endospore densities of $P$. penetrans in the different crop sequences appear to be related to the amount and frequency of $M$. arenaria reproduction. Oostendorp et al. (21) observed greater endospore attachment to $\mathrm{J} 2$ of $M$. arenaria in the spring following vetch, a good host for the nematode, than following rye, a poor host, or following fallow. The moderately high endospore densities observed in the bahiagrass-peanut rotations were probably due to the presence of weed hosts in the first year of bahiagrass resulting in nematode and $P$. penetrans reproduction 2 out of 3 years in these plots. Because we did not determine densities of endospores until 8 and 9 years after the study was initiated, we do not know how rapidly endospore densities increased or decreased under different crop sequences.

Aldicarb has no direct effect on the viability of $P$. penetrans endospores (17); however, the nematicide probably indirectly affects the bacterium by reducing numbers of $M$. arenaria. Nevertheless, we did not observe a reduction in abundance of endospores in aldicarb-treated plots. Perhaps our bioassay was not sensitive enough to detect differences in endospore numbers between aldicarb-treated and control plots. The effect of aldicarb on reproduction of $M$. arenaria and $P$. penetrans would be relatively small compared with the effect of planting a nonhost of the nematode.

Previous studies have demonstrated reduction in southern stem rot incidence in peanut following rotation with bahiagrass, corn, and cotton $(4,13,23)$. We observed disease suppression in peanut following bahiagrass, but not corn and cotton. These results support those of Johnson et al. (14), who found that bahiagrass rotations were superior to corn or cotton rotations in suppression of stem rot in peanut.

Application of aldicarb can have variable effects on the incidence of stem rot in peanut. While most studies have not observed an effect of aldicarb on stem rot (19,23-25), two studies have shown a reduction in the incidence of this disease in plots treated with the nematicide compared with untreated plots $(6,27)$. To our knowledge, we are the first to report an increase in the incidence of stem rot in peanut in aldicarb-treated compared with control plots. Disease incidence was higher in aldicarb-treated plots in all 3 years of this study, and in 3 of the 6 years from 1991 to 1996 (A. W. Johnson, unpublished); however, when the 6 years were combined, there was no effect of aldicarb on stem rot (13). Greater canopy cover in the aldicarbtreated plots may have provided a conducive environment for infection by $S$. rolfsii (1). Although we did not collect data on the peanut canopy, canopy widths in plots treated with aldicarb were noticeably greater than in plots without aldicarb early in the season, but widths were similar in all plots late in the season. Aldicarb may have had a direct effect on plant growth (2) or an indirect effect on growth by suppressing thrips damage. Growth of peanut plants can be stunted by early-season thrips injury; however, the plant eventually recovers and peanut yield is not affected (10). The percentage of leaflets damaged by thrips was threefold greater in plots without aldicarb than in plots treated with aldicarb. Application of flutolanil ameliorated the heightened stem rot incidence in plots treated with aldicarb.

Aldicarb alone did not increase peanut yield. It is likely that any yield benefits from nematode and thrips suppression would have been negated by the increase in damage from $S$. rolfsii. However, peanut yields were higher in plots treated with aldicarb and flutolanil than in plots treated with the fungicide alone, suggesting that nematodes and/or thrips were limiting yield.

Pasteuria penetrans may have maintained low and perhaps even nondamaging populations of $M$. arenaria in the continuous peanut plots. Nevertheless, peanut yields were lower in the continuous peanuts than in corn or bahiagrass rotations in 1997 to 1999 and lower than in all rotations in 1991 to 1996 (14). M. arenaria did not contribute to these yield differences in 1997 to 1999 because root gall indices on peanut were similar in continuous peanut and in rotations with corn and bahiagrass. Suppression of $S$. rolfsii during the 2 years of bahiagrass probably contributed to the higher yields in the bahiagrass-peanut rotation compared with continuous peanut.

\section{AKNOWLEDGMENTS}

We thank D. L. Clements, W. H. Wilson, T. L. Hilton, J. A. Mixon, K. L. Mullis, T. L. Howell, L. G. Thompson, W. E. Cook, B. H. Baldree, and E. $\mathrm{T}$. Tucker for their dedicated assistance in data collection and crop management. We thank R. C. Layton for help with statistical analysis, and D. R. Sumner and R. F. Davis for critical review of the manuscript. We are also grateful for support provided by the Georgia Agricultural Commodity Commission for Peanuts.

\section{LITERATURE CITED}

1. Backman, P. A., Rodriguez-Kabana, R., and Williams, J. C. 1975. The effect of peanut leafspot fungicides on the nontarget pathogen, Sclerotium rolfsii. Phytopathology 65:773776.

2. Barker, K. R., Koenning, S. R., Bostian, A. L., and Ayers, A. R. 1988. Growth and yield responses of soybean to aldicarb. J. Nematol. 20:421-431.

3. Bird, A. F., and Brisbane, P. G. 1988. The influence of Pasteuria penetrans in field soils on the reproduction of root-knot nematodes. Rev. Nematol. 11:75-81.

4. Brenneman, T. B., Sumner, D. R., Baird, R. E., Burton, G. W., and Minton, N. A. 1995. Suppression of foliar and soilborne peanut diseases in bahiagrass rotations. Phytopathology 85:948-952.

5. Chen, Z. X., and Dickson, D. M. 1998. Re- view of Pasteuria penetrans: Biology, ecology, and biological control potential. J. Nematol. 30:313-340.

6. Culbreath, A. K., Minton, N. A., Brenneman, T. B., and Mullinix, B. G. 1992. Response of florunner and southern runner peanut cultivars to chemical management of late leaf spot, southern stem rot, and nematodes. Plant Dis. 76:1199-1203.

7. Davies, K. G., Laird, V., and Kerry, B. R. 1991. The motility, development and infection of Meloidogyne incognita encumbered with spores of the obligate hyperparasite Pasteuria penetrans. Rev. Nematol. 14:611-618.

8. Davis, R. F., and Timper, P. 2000. Resistance in selected corn hybrids to Meloidogyne arenaria and $M$. incognita. Suppl. J. Nematol. 32:633-640.

9. Delaplane, K. S., ed. 1996. Georgia Pest Control Handbook. Cooperative Extension Service, University of Georgia, Athens.

10. Herbert, D. A., Jr., Wilcut, J. W., and Swann, W. C. 1991. Effects of various postemergence herbicide treatments and tobacco thrips (Frankliniella fusca) injury on peanut yields in Virginia. Peanut Sci. 18:91-94.

11. Hussey, R. S., and Barker, K. R. 1973. A comparison of methods of collecting inocula for Meloidogyne spp., including a new technique. Plant Dis. Rep. 57:1025-1028.

12. Jenkins, W. R. 1964. A rapid centrifugalflotation technique for separating nematodes from soil. Plant Dis. Rep. 48:692.

13. Johnson, A. W., Minton, N. A., Brenneman, T. B., Burton, G. W., Culbreath, A. K., Gascho, G. J., and Baker, S. H. 1999. Bahiagrass, corn, cotton rotations, and pesticides for managing nematodes, diseases, and insects on peanut. J. Nematol. 31:191-200.

14. Johnson, A. W., Minton, N. A., Brenneman, T. B., Burton, G. W., Culbreath, A. K., Gascho, G. J., Baker, S. H., and Johnson, W. C., III. 1999. Managing nematodes, fungal diseases, and thrips on peanut with pesticides and crop rotations of bahiagrass, corn, and cotton. Peanut Sci. 26:32-39.

15. Koenning, S. R., Overstreet, C., Noling, J. W., Donald, P. A., Becker, J. O., and Fortnum, B A. 1999. Survey of crop losses in response to phytoparasitic nematodes in the United States. Suppl. J. Nematol. 31:587-618.

16. Kokalis-Burelle, N., Porter, D. M., RodriguezKabana, R., Smith, D. H., and Subrahmanyam, P., eds. 1997. Compendium of Peanut Diseases, 2nd ed. American Phytopathological Society, St. Paul, MN.

17. Mankau, R., and Prasad, N. 1972. Possibilities and problems in the use of a sporozoan endoparasite for biological control of plant parasitic nematodes. Nematropica 2:7-8.

18. Mankau, R., and Prasad, N. 1977. Infectivity of Bacillus penetrans in plant-parasitic nematodes. J. Nematol. 9:40-45.

19. Minton, N. A., Csinos, A. S., Lynch, R. E., and Brenneman, T. B. 1991. Effects of two cropping and two tillage systems and pesticides on peanut pest management. Peanut Sci. 18:41-46.

20. Minton, N. A., and Sayre, R. M. 1989. Suppressive influence of Pasteuria penetrans in Georgia USA soils on reproduction of Meloidogyne arenaria. J. Nematol. 21:574-575.

21. Oostendorp, M., Dickson, D. W., and Mitchell, D. J. 1991. Population development of Pasteuria penetrans on Meloidogyne arenaria. J. Nematol. 23:58-64.

22. Plank, C. O. 1989. Soil Test Handbook for Georgia. Cooperative Extension Service, University of Georgia, Athens.

23. Rodriguez-Kabana, R., Kokalis-Burelle, N., Robertson, D. G., King, P. S., and Wells, L. W. 1994. Rotations with coastal bermudagrass, cotton, and bahiagrass for management 
of Meloidogyne arenaria and southern blight in peanut. Suppl. J. Nematol. 26:665-668.

24. Rodriguez-Kabana, R., Robertson, D. G., King, P. S., and Wells, L. 1991. American jointvetch and partridge pea for the management of Meloidogyne arenaria in peanut. Nematropica 21:97-103.

25. Rodriguez-Kabana, R., Robertson, D. G., Wells, L., Weaver, C. F., and King, P. S. 1991. Cotton as a rotation crop for the management of Meloidogyne arenaria and Sclerotium rolf- sii in peanut. J. Nematol. 23(suppl.):652-657.

26. Rodriguez-Kabana, R., Robertson, D. G., Weaver, C. F., and Wells, L. 1991. Rotations of bahiagrass and castorbean with peanut for the management of Meloidogyne arenaria. J. Nematol. 23:658-661.

27. Rodriguez-Kabana, R., Shelby, R. A., King, P. S., and Pope, M. H. 1982. Application time and effectiveness of four systemic nematicides against Meloidogyne arenaria on Florunner peanuts. Nematropica 12:85-96.
28. Sayre, R. M. 1980. Biocontrol: Bacillus penetrans and related parasites of nematodes. J. Nematol. 12:260-270.

29. Sumner, D. R. 1982. Crop rotation and plant productivity. Pages 273-313 in: CRC Handbook of Agricultural Productivity, vol. 1. M. Rechighl, Jr., ed. CRC Press, Boca Raton, FL.

30. Weibelzahl-Fulton, E., Dickson, D. W., and Whitty, E. B. 1996. Suppression of Meloi dogyne incognita and $M$. javanica by Pasteuria penetrans in field soil. J. Nematol. 28:43-49. 